\title{
Extracellular GTP is a Potent Water- Transport Regulator via Aquaporin 5 Plasma-Membrane Insertion in M1-CCD Epithelial Cortical Collecting Duct Cells
}

\author{
Rosa Mancinellia,b,c Rita Maria Laura La Rovere ${ }^{a, b, c}$ Stefania Fulle ${ }^{a, b, c}$ \\ Sebastiano Miscia ${ }^{b, d}$ Marco Marchisio ${ }^{b, d}$ Laura Pierdomenico ${ }^{b, d}$ Paola Lanutib,d \\ Giuseppe Procino Claudia Barbierie Maria Svelto ${ }^{e}$ Giorgio Fanò-Illic a,c,f \\ Tiziana Pietrangelo $o^{a, b, c, f}$
}

a'Department of Neurosciences and Imaging (DNI), 'G. d'Annunzio' University of Chieti-Pescara, ' ${ }^{b}$ Centre for Aging Sciences (Ce.S.I.), 'G. d'Annunzio' University Foundation, 'Interuniversity Institute of Myology, dDepartment of Medicine and Aging Science (D.M.S.I.), 'G. d'Annunzio' University of Chieti-Pescara, Chieti, eDepartment of Biosciences, Biotechnologies and Biopharmaceutics, University of Bari, Bari, fClinical Research Centre (C.R.C.), 'G. d'Annunzio' University Foundation, Chieti, Italy

\section{Key Words}

Epithelial cells $\bullet$ Kidney $\bullet$ GTP $•$ AQP5 $・$ Water channel $\bullet$ Cell cycle $・$ M1-CCD cells

\begin{abstract}
Background/Aims: Extracellular GTP is able to modulate some specific functions in neuron, glia and muscle cell models as it has been demonstrated over the last two decades. In fact, extracellular GTP binds its specific plasma membrane binding sites and induces signal transduction via $\left[\mathrm{Ca}^{2+}\right]$. increase. We demonstrate, for the first time, that extracellular GTP is able to modulate cell swelling in M1-CCD cortical collecting duct epithelial cells via upregulation of aquaporin 5 (AQP5) expression. Methods: We used videoimaging, immunocitochemistry, flow cytometry, confocal techniques, Western blotting and RT-PCR for protein and gene expression analysis, respectively. Results: We demonstrate that AQP5 mRNA is up-regulated $7 \mathrm{~h}$ after the GTP exposure in the cell culture medium, and its protein level is increased after 12-24 h. We show that AQP5 is targeted to the plasma membrane of M1-CCD cells, where it facilitates cell swelling, and that the GTP-dependent AQP5 up-regulation occurs via $\left[\mathrm{Ca}^{2+}\right]_{i}$ increase. Indeed, GTP induces both oscillating and transient $\left[\mathrm{Ca}^{2+}\right]_{i}$ increase, and specifically the oscillating kinetic appears to be responsible for blocking cell cycle in the S-phase while the $\left[\mathrm{Ca}^{2+}\right]_{i}$ influx, with whatever kinetic, seems to be responsible for inducing AQP5 expression. Conclusion: The role of GTP as a regulator of AQP5-mediated water transport in renal cells is of great importance in the physiology of renal epithelia, due to its possible physiopathological implications. GTP-dependent AQP5 expression could act as osmosensor. In addition, the data presented here suggest that GTP might play the same role in other tissues where rapid water transport is required for cell volume regulation and maintenance of the homeostasis.
\end{abstract}

Copyright (c) 2014 S. Karger AG, Basel 
Mancinelli et al.: GTP Induces AQP5 Expression in Renal Epithelial Cells

\section{Introduction}

The P2 purinoceptors are a family of ATP-gated receptors that are expressed on epithelial cells of the kidney, in the apical and basolateral membranes of the distal nephron and in the cortical collecting duct. The P2 family $[1,2]$ comprises two subtypes, P2X receptors, which are ionotropic ATP-gated receptor channels, and P2Y receptors, which are metabotropic G-protein-coupled receptors. GTP has been demonstrated to activate the P2Y2 receptor, as also seen for ATP and UTP [3, 4]. Moreover, the role of GTP as a physiological mediator has received strong support from data produced in our laboratory confirming the presence of specific binding sites for GTP on the plasma membrane of both neuronallike cells and myogenic cells $[5,6]$. Indeed, guanine-based purines have been demonstrated to participate in trophism of glia cells and neuritogenesis [7-9]. The literature on acute extracellular GTP signal transduction describes a GTP-dependent increase in intracellular $\mathrm{Ca}^{2+}$ concentrations $\left(\left[\mathrm{Ca}^{2+}\right]_{\mathrm{i}}\right)$. In particular, in $\mathrm{C} 2 \mathrm{C} 12$ myoblasts, the GTP-dependent $\left[\mathrm{Ca}^{2+}\right]_{\mathrm{i}}$ increase arises through the release of $\mathrm{Ca}^{2+}$ from intracellular stores, with the activation of intermediate $\mathrm{Ca}^{2+}$-activated $\mathrm{K}^{+}$channels, which hyperpolarize the membrane potential [10]. This GTP-dependent signal induces specific gene expression that can modulate myoblast differentiation [11]. Moreover, the data already present in the literature show that GTP regulates cell proliferation, by causing a block of cells in the S-phase of the cell cycle $[10,12]$. Other studies have demonstrated that the intracellular GTP concentration and the rate of GTP synthesis/ degradation are important regulators of cell fate, which results in cell death when GTP is too low [13].

It has been shown that, by acting in paracrine and autocrine manners, extracellular ATP binds P2Y2 receptors and modulates salt reabsorption in the kidney collecting ducts. In particular, ATP inhibits both $\mathrm{Na}^{+}$reabsorption, through $\mathrm{EnaC}$, and water reabsorption, through aquaporin 2 (AQP2) (reviewed by Vallon et al. [14]). Specifically, data obtained on mpkCCD cells showed the expression of significant amounts of mRNA of P2 receptors (P2X2, P2X4, P2X5, and P2X7 subunits, and for P2Y1, P2Y2, and P2Y4 receptors) and their involvement in the down-regulation of AQP2 [15]. However, despite the emerging role of ATP in renal physiology, there are no reports of the effects of extracellular GTP on epithelial renal cells.

Strikingly, in the present study, we describe a novel role of extracellular GTP as a modulator of plasma-membrane water permeability in a mouse cortical collecting duct cell line, M1-CCD cells [16]. We demonstrate that extracellular GTP increases the water permeability and cell swelling of M1-CCD cells in vitro by inducing the expression of the water channel AQP5. Interestingly, we recently reported the novel observation that adult renal progenitor/stem cells (ARPC) and type-B intercalated cells (ICs) in the collecting duct express AQP5 at the apical plasma membrane and proposed a role of AQP5 as osmosensor of the tonicity of the extracellular fluid [17].

These observations in renal cell culture may open a new field of investigation towards our understanding of the roles of extracellular GTP in renal physiology and pathophysiology.

\section{Materials and Methods}

\section{Cell culture and reagents}

The M1-CCD cell line (CRL-2038; American Type Culture Collection, Manassas, VA, USA) was derived from renal collecting duct cells that were microdissected from a mouse that was transgenic for the early region of SV40 virus [strain $\mathrm{Tg}(\mathrm{SV} 40 \mathrm{E})$ Bri7] [16]. M1-CCD cells were routinely grown in $56.7 \mathrm{~cm}^{2}$ polystyrene culture dishes containing growth medium (Dulbecco's modified Eagle's medum [DMEM]/ Ham's F-12 [1:1, DMEM/F-12; \#21041025, Invitrogen] with 5\% fetal bovine serum [\#ECS0180L, Euroclone], 100 U/ $\mathrm{ml}$ penicillin, and $100 \mu \mathrm{g} / \mathrm{ml}$ streptomycin (\#ECB3001D, Euroclone). The cultures were maintained in an atmosphere of $100 \%$ humidity in $5 \% \mathrm{CO}_{2}$ at $37^{\circ} \mathrm{C}$. The medium was changed every 2 to 3 days, and the cells were subcultured at confluence, using trypsinization. 
Mancinelli et al.: GTP Induces AQP5 Expression in Renal Epithelial Cells

The following reagents were purchased from Sigma-Aldrich Srl (St. Louis, MO, USA): guanosine 5'-triphosphate (GTP, G5884), adenosine 5'-triphosphate (ATP, A6419), guanosine (G6264), forskolin (F3917), suramin (S2671), and reactive blue 2 (RB2; Basilen Blue E-G3, B5520); all reagents were used without any purification step.

Wheat germ agglutinin, Alexa Fluor 555 conjugate was purchased from Life Technologies (www. lifetechnologies.com).

\section{Antibodies}

Antibodies against an extracellular epitope of AQP2/AQP5 were generated by immunization of rabbits with a synthetic peptide that reproduced the sequence of the human AQP2 extracellular C-loop (IRGDLAVNALSNSTT, 80\% identical to mouse AQP5 C-loop peptide ARGNLAVNALSNNTT), as previously published [18]. Rabbit-anti-rat AQP5 antibodies were used for immunoblotting (Alomone Labs; www. alomone.com).

Primary antibodies were labeled using the fluorescein isothiocyanate (FITC) Zenon Antibody Labeling kits (Gibco, Invitrogen, Carlsbad, CA, USA), following the manufacturer instructions. All of the antibodies were titrated to obtain their optimal dilutions for the experimental settings.

\section{Apparatus and chromatographic conditions}

The HPLC set-up comprised an Agilent 1100 series autosampler (G1329A), and a column oven (G1316A), degasser (G1322A), quaternary pump (G1311A) and UV detector (G1315B). The instrumental control and data acquisition and processing were all carried out using ChemStation software (Agilent Technologies, Wokingam, UK). A Discovery C18 $250 \times 4.6 \mathrm{~mm}$ column fitted with a guard column (Supelco) was used for the chromatographic separation. The column was kept at $40{ }^{\circ} \mathrm{C}$, and the detection absorption wavelength was set at $254 \mathrm{~nm}$. The mobile phase consisted of a gradient mix of $50 \mathrm{mM}$ phosphate buffer $\left(\mathrm{K}_{2} \mathrm{HPO}_{4}, \mathrm{KH}_{2} \mathrm{PO}_{4}\right.$ and $10 \mathrm{mM}$ tetrabutylammonium hydrogen sulphate, TBAHS; solution A) adjusted to $\mathrm{pH}$ 6 , and acetonitrile (solution $\mathrm{B}$ ) at concentrations that varied from $0 \%$ to $30 \%$ over the duration of the HPLC run, as follows: 0-5 min, 0\% B; 5-10 min, 0\%-30\% B; 10-30 min, 30\% B; 30-32 min, 30\%-0\% B; 32-45 $\min , 0 \% \mathrm{~B}$. The flow rate was set at $1 \mathrm{~mL} \mathrm{~min}^{-1}$. The injection volume was $50 \mu \mathrm{L}$ for all of the samples. The samples were kept at $4^{\circ} \mathrm{C}$ in the autosampler for no longer than $12 \mathrm{~h}$ before injection. GTP was identified on the basis of its retention time (17.5 $\mathrm{min})$.

\section{Confocal microscopy}

M1-CCD cells $\left(3,000\right.$ cells $\left./ \mathrm{cm}^{2}\right)$ were seeded in 96-well plates with optical membranes (\#3614, Corning) and grown for 3 to 5 days. Fluorescent images were obtained using a Bio-Rad MRC-1000 inverted confocal microscope system with a Zeiss 63x/1.25 PLAN NEOFLUAR oil-immersion objective (Zeiss, Jena, Germany). The cells were then fixed and stained with wheat germ agglutinin WGA-555 (W32464, Invitrogen) conjugated with Alexa Fluor ${ }^{\circledR} 555$ dye (excitation/emission maxima $\sim 555 / 565 \mathrm{~nm}$ ). Alexa Fluor ${ }^{\circledR} 555$ WGA binds to sialic acid and N-acetylglucosaminyl residues. The laser potency, photomultiplier settings and pin-hole size were kept constant for the entire series of experiments.

Cell surface area from at least 20 cells per experimental condition was accurately quantified in 3 independent experiments using Image J (http://rsb.info.nih.gov) and expressed as percentage of control cells area.

\section{Intracellular $\mathrm{Ca}^{2+}$ measurements}

For the measurement of intracellular $\mathrm{Ca}^{2+}$ concentration $\left(\left[\mathrm{Ca}^{2+}\right]_{\mathrm{i}}\right), 3,000 \mathrm{M} 1-\mathrm{CCD}$ cells $\mathrm{cm}^{-2}$ were seeded in 96-well plates with optical membranes (\#3614, Corning) and grown in growth medium for 3 to 5 days, with the medium changed every 2 days. We tested 75 to 100 cells for each experimental protocol.

The M1-CCD cells were incubated for $45 \mathrm{~min}$ at $37^{\circ} \mathrm{C}$ in normal extracellular solution ( $10 \mathrm{mM}$ glucose, $140 \mathrm{mM} \mathrm{NaCl}, 2.8 \mathrm{mM} \mathrm{KCl}, 2 \mathrm{mM} \mathrm{CaCl}{ }_{2}, 2 \mathrm{mM} \mathrm{MgCl}_{2}$ and $10 \mathrm{mM}$ HEPES, pH 7.4) supplemented with $10 \mathrm{mg}$ $\mathrm{ml}^{-1}$ bovine serum albumin and $5 \mu \mathrm{M}$ Fura-2AM (\#F1221, Molecular Probes). The samples were treated and the images were collected as described previously [6]. The acquisition time for each fluorescence emission was $5 \mathrm{~s}$. Temporal plots were calculated for the entire cell area as the mean values of the ratios between the $340 \mathrm{~nm}$ and $380 \mathrm{~nm}$ fluorescence signals: $f$ and $f_{0^{\prime}}$, respectively. 
Mancinelli et al.: GTP Induces AQP5 Expression in Renal Epithelial Cells

\section{Real-time PCR}

For the real-time PCR, the M1-CCD cells were cultured for $12 \mathrm{~h}, 24 \mathrm{~h}, 48 \mathrm{~h}$ and $72 \mathrm{~h}$ in the absence and presence of $500 \mu \mathrm{M}$ GTP, $500 \mu \mathrm{M}$ guanosine and $100 \mu \mathrm{M}$ ATP. The total RNA was isolated using Tri Reagent (Sigma), according to the manufacturer instructions. Moreover, we stimulated the cells with GTP for $1 \mathrm{~h}, 3$ $\mathrm{h}$ and $7 \mathrm{~h}$ in the absence or presence of extracellular $\mathrm{Ca}^{2+}( \pm 2 \mathrm{mM}$ EGTA in the medium $)$ and continued the incubation with fresh medium for up to a total incubation time of $24 \mathrm{~h}$. The cells were then collected for RNA extraction.

For cDNA synthesis, $20 \mu \mathrm{l}(1 \mu \mathrm{g})$ total RNA was directly processed with High-Capacity cDNA Archive kits (Applied Biosystems), according to the manufacturer instructions. Singleplex real-time PCR was performed for the relative quantification of gene expression of $A Q P 2$ (the aquaporin 2 gene), $A Q P 5, A Q P 6, P 2 Y 2$ and P2Y4 versus GAPDH (the glyceraldehyde-3-phosphate dehydrogenase gene), using TaqMan technology on an ABI Prism 9700HT Sequence Detection System instrument, connected to Sequence Detector Software (SDS, version 2.0) for data collection and analysis. The primer pairs and TaqMan probes for all of the target genes and for the GAPDH reference gene were provided as $20 \times$ mixtures that were ready to use at a final concentration of $1 \times$. According to the manufacturer recommendations, $25 \mu$ reactions were performed in a MicroAmp Optical 96-well reaction plate using $12.5 \mu \mathrm{l} 2 \times$ TaqMan Universal PCR Master mix, with $1.25 \mu \mathrm{l}$ $20 \times$ Inventoried Gene Expression Product for the mouse $A Q P 2$ target gene, AQP5, AQP6, P2Y2 or P2Y4 versus GAPDH (FAM-dye-labeled TaqMan MGB probe). For each sample, the cDNA was diluted in RNase-free water to the final $25 \mu \mathrm{l}$ reaction volume. PCR was performed at $50{ }^{\circ} \mathrm{C}$ for $2 \mathrm{~min}$, and at $95^{\circ} \mathrm{C}$ for $10 \mathrm{~min}$, and then run for 45 cycles at $95^{\circ} \mathrm{C}$ for $15 \mathrm{~s}$ and at $60^{\circ} \mathrm{C}$ for $1 \mathrm{~min}$. All of the reactions were performed in triplicate, and each experiment was repeated three times. The results were exported from the ABI Prism 9700HT Sequence Detection System into Microsoft Excel files for further analysis. The relative quantification of target gene expression was evaluated with data from the SDS software, using the arithmetic formula $2^{-\Delta \Delta C t}$, according to the comparative Ct method, which represents the amount of target, as normalised to the GAPDH endogenous control (reference). All materials, instruments and software were purchased from Applied Biosystems.

\section{Cell staining of AQPs for flow cytometry}

M1-CCD cells were seeded at a density of 5,000 cells $\mathrm{cm}^{-2}$ in collagen-coated Petri dishes, and after incubations for 3 days with $500 \mu \mathrm{M}$ GTP they were detached by gentle scraping. We did not use trypsin to detach these cells to avoid AQP extracellular peptide cutting. All of the washing steps were carried out using $0.5 \%$ bovine serum albumin, $0.1 \%$ sodium azide in phosphate-buffered saline (PBS) as washing buffer, followed by centrifugation $\left(400 \times \mathrm{g}, 8 \mathrm{~min}, 4^{\circ} \mathrm{C}\right)$. The cell staining was performed as reported previously [19]. Briefly, $1 \times 10^{6}$ cells/sample were washed, resuspended in $100 \mu \mathrm{l}$ antibody, and incubated for $30 \mathrm{~min}$ at $4{ }^{\circ} \mathrm{C}$ in the dark. The cells were washed and then $20 \mu \mathrm{l}$ cell viability solution (Via-Probe, BD Biosciences, San Jose, CA, USA) was added to each tube $10 \mathrm{~min}$ before the analysis.

The samples were then acquired on a FACSCalibur flow cytometer (two-lasers, four-color configuration) equipped with CellQuest 3.2.1.f1 software (BD Biosciences). The data were analyzed using the FlowJ software (TreeStar, Ashland, OR, USA).

Quality control included regular checks with Rainbow Calibration Particles (6 peaks; BD Biosciences). In each analysis 1,000,000 total events were recorded. To evaluate nonspecific fluorescence when defining positive events, we used Fluorescence Minus One controls [20, 21].

\section{Fluorescence-quenching assays for water-transport measurements}

Water-permeability assays were carried out using a bench-top fluorescence plate reader with integrated liquid handling (FlexStation II, Molecular Devices, MDS Analytical Technologies, USA) that was equipped to analyze real-time fluorescence kinetics data in a 96-well format, as described previously [22].

The M1-CCD cells were seeded in 96-well black, clear-bottomed microplates (Corning-Costar Corp., Corning, NY, USA) and cultured for $24 \mathrm{~h}, 48 \mathrm{~h}$ and $72 \mathrm{~h}$ in the absence or presence of $500 \mu \mathrm{M}$ GTP.

Our strategy was based on the calcein-quenching method. The cells were washed in PBS and incubated at $37{ }^{\circ} \mathrm{C}$ for $60 \mathrm{~min}$ with PBS containing $10 \mu \mathrm{M}$ membrane-permeable calcein-AM (Molecular Probes, Eugene, OR, USA). The nonfluorescent calcein acetoxymethyl ester (AM) is converted to greenfluorescent calcein after AM hydrolysis by intracellular esterases. The resulting membrane-impermeable calcein fluorophore undergoes self-quenching, and so its fluorescence intensity decreases with increasing 
fluorophore concentration. Accordingly, the self-quenching properties can be used for measuring water volume changes in lipid vesicles or in living cells, as in the present study.

To verify that the water transport induced by GTP was mediated by AQPs, the cells were treated for 2 min with $0.2 \mathrm{mM} \mathrm{HgCl}_{2}$. Sulfhydryl-reactive mercurials, such as $\mathrm{HgCl}_{2}$, are the best-established inhibitors of most $\mathrm{AQP}$ water channels.

At the end of the incubations, the calcein was washed out, and $50 \mu$ of isosmotic PBS (with $\mathrm{Ca}^{2+}$ and $\mathrm{Mg}^{2+}$ ) were added to each well. The microplates were then transferred into the plate reader for the fluorescence measurements. The time course of fluorescence was recorded continuously for $15 \mathrm{~s}$ (baseline), then for $35 \mathrm{~s}$ after rapid automated addition of $50 \mu \mathrm{l}$ distilled water (hyposmotic shock), and for $40 \mathrm{~s}$ after automated addition of $15 \mu \mathrm{l} 1 \mathrm{M}$ mannitol to restore isosmotic conditions. Measurements were taken every $0.5 \mathrm{~s}$. The fluorescence assays were carried out at $18^{\circ} \mathrm{C}$. Data acquisition was performed using the SoftMax Pro software.

The time constant of cell swelling induced by the hyposmotic stimulus was obtained by fitting the line of the tangent to the first part of the curve, using linear regression. The data were expressed as $1 / \tau\left(\mathrm{s}^{-1}\right)$. Values were expressed as \% of the M1-CCD cell control at each time point.

\section{Protein extraction and Western blotting}

The M1-CCD cells were cultured for $0,24 \mathrm{~h}, 48 \mathrm{~h}$ and $72 \mathrm{~h}$ in the absence and presence of $500 \mu \mathrm{M}$ GTP. The cells were then solubilized in RIPA buffer $(150 \mathrm{mM} \mathrm{NaCl}, 10 \mathrm{mM}$ Tris, $\mathrm{pH} 7.2,0.1 \%$ SDS, $1 \%$ Triton X-100, 1\% deoxycholate, $5 \mathrm{mM}$ EDTA) containing protease inhibitors $(20 \mathrm{mmol} / \mathrm{l}$ pepstatin, 20 $\mathrm{mmol} / \mathrm{l}$ leupeptin, and $1 \mathrm{mmol} / \mathrm{l}$ phenylmethylsulfonyl fluoride). The lysates were sonicated for 30 $\mathrm{s}$ and centrifuged at $13,000 \times \mathrm{g}$ for $15 \mathrm{~min}$ at $4{ }^{\circ} \mathrm{C}$ The protein concentrations of the supernatants were determined. Protein extracts were separated by SDS-PAGE on $12 \%$ polyacrylamide gels under reducing conditions. Total extracts from mouse lung were load in parallel and used as the positive control for AQP5 immunodetection. Protein bands were electrophoretically transferred to ImmobilonP membranes (www. millipore.com) for Western blotting, blocked in TBS Tween containing 3\% BSA, and incubated with the primary antibodies. The immunoreactive bands were detected with the secondary antibody conjugated to horseradish peroxidase. After each step, the membranes were washed with TBS Tween. Membranes were developed with SuperSignal West Pico Chemiluminescent Substrate (www.piercenet.com) and the chemiluminescence detected using a Chemidoc ${ }^{\mathrm{TM}} \mathrm{XRS}$ detection system equipped with Image Lab ${ }^{\mathrm{TM}}$ Software for image acquisition and densitometry (www.bio-rad.com).

\section{Proliferation assays}

Cell proliferation was determined using a colorimetric assay of 3-[4,5-dimethylthiazol-2-yl]-2,5diphenyltetrazolium bromide (MTT, \#M2128, Sigma). We seeded 3,000 cells $\mathrm{cm}^{-2}$ per well in a final volume of $200 \mu$ growth medium, in 96-well plates. These M1-CCD cells were incubated with stimuli for different times. The incubations were terminated by the addition of $20 \mu \mathrm{l}$ MTT solution ( $5 \mathrm{mg} \mathrm{mL}^{-1}$ in PBS) to each well, followed by incubation at $37^{\circ} \mathrm{C}$ for $3 \mathrm{~h}$. The supernatants were removed, $200 \mu \mathrm{l}$ dimethylsulfoxide (\#D4540, Sigma) was added to each well, and incubated for $30 \mathrm{~min}$ at $37^{\circ} \mathrm{C}$. The plates were read at $540 \mathrm{~nm}$ on a Titertek Multiscan Microelisa Reader (Flow Laboratories, Urvine, UT, USA).

\section{BrdU incorporation and detection}

Exponentially growing cells were exposed to $10 \mu \mathrm{M}$ bromodeoxyuridine (BrdU) (Sigma) for $1 \mathrm{~h}$, and then fixed in $70 \%$ ethanol and kept at $4{ }^{\circ} \mathrm{C}$ before labeling, as described previously [23].

To detect BrdU incorporation, the cells were washed with PBS and treated with $1 \mathrm{ml} 2 \mathrm{~N} \mathrm{HCl} / 0.5 \%$ Triton X-100 (Sigma), for $30 \mathrm{~min}$ at room temperature. One ml per sample of $0.1 \mathrm{M} \mathrm{Na}_{2} \mathrm{~B}_{4} \mathrm{O}_{7}(\mathrm{pH}$ 8.57) was added to stop the $\mathrm{HCl}$ reaction. The cells were then washed with $1 \mathrm{ml} 0.5 \%$ Triton $\mathrm{X}-100 / 1 \%$ bovine serum albumin, followed by incubation with a FITC-conjugated anti-BrdU antibody (BD Biosciences; dilution: $1: 5$ in $0.5 \%$ [v/v] Triton X-100) for $30 \mathrm{~min}$ at room temperature in the dark. The cells were washed and resuspended in $5 \mu \mathrm{g} / \mathrm{ml}$ propidium iodide (Sigma) and $200 \mu \mathrm{g} / \mathrm{ml} \mathrm{RNase} \mathrm{(Sigma).} \mathrm{After} 30 \mathrm{~min}$ of incubation, biparametric BrdU/DNA data were acquired on a FACSCalibur flow cytometer (two-lasers, fourcolor configuration) using the CellQuest 3.2.1.f1 software (BD Biosciences); the data were analyzed using the FlowJo software (TreeStar, Ashland, OR, USA) or the ModFit LT software (Verity Software House, Toshan, ME, USA). Cell debris was excluded from the analysis by gating a forward scatter versus side scatter plot. 
A

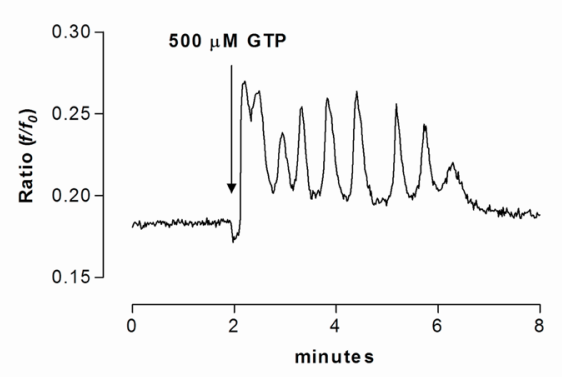

C

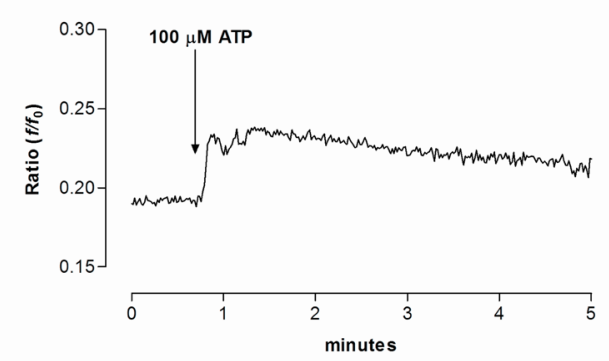

B

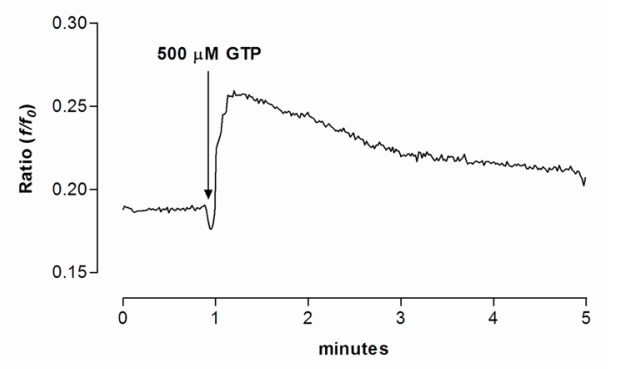

D

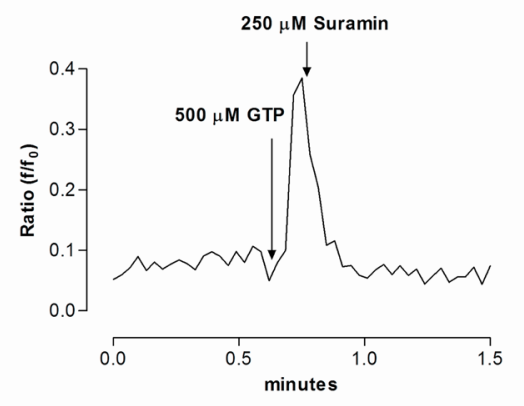

Fig. 1. GTP-induced and ATP-induced $\left[\mathrm{Ca}^{2+}\right]_{\text {i }}$ responses in M1 kidney CCD cells. Representative epifluorescence ratios $\left(f / f_{0}\right)$ recorded from single M1-CCD cells loaded with Fura 2 and stimulated, in the presence of $\mathrm{Ca}^{2+}$, with $500 \mu \mathrm{M}$ GTP (A, B, D) or $100 \mu \mathrm{M}$ ATP (C) (as indicated by the arrows). The signals show significant $\left[\mathrm{Ca}^{2+}\right]_{\mathrm{i}}$ increases with $500 \mu \mathrm{M}$ GTP, with two different kinetics: oscillatory $\left[\mathrm{Ca}^{2+}\right]_{\mathrm{i}}$ increases (A; $25 \%$ of cells; $\mathrm{n}=71$ ) and transient $\left[\mathrm{Ca}^{2+}\right]_{\mathrm{i}}$ increases (B; $75 \%$ of cells; $\mathrm{n}=71$ ), both of which lasted about 5 min. (C) Typical $\mathrm{Ca}^{2+}$ transient of single M1-CCD cells stimulated with $100 \mu \mathrm{M}$ ATP $(\mathrm{n}=100)$. The $\left[\mathrm{Ca}^{2+}\right]_{\mathrm{i}}$ transient increase returned to basal in about $5 \mathrm{~min}$. (D) $\left[\mathrm{Ca}^{2+}\right]_{\mathrm{i}}$ response after $500 \mu \mathrm{M}$ GTP and 250 $\mu \mathrm{M}$ suramin, as indicated. Suramin abolishes the GTP-dependent $\left[\mathrm{Ca}^{2+}\right]_{\mathrm{i}}$ increase, with an immediate return to basal $\left[\mathrm{Ca}^{2+}\right]_{\mathrm{i}}(\mathrm{n}=27)$.

Cell aggregates were excluded by gating FL2 area versus FL2 width [19]. The low flow rate mode (400-500 events/s) was used to record 20,000 nondebris events for each sample. Propidium iodide fluorescence data were collected using linear amplification. DNA content was assessed, placing the G1 peak around channel 400. Single stained samples were used to manually assess the compensation. Quality control included regular checks with Rainbow Calibration Particles (6 peaks, BD Biosciences).

\section{Statistical analysis}

The data on single cells for $\left[\mathrm{Ca}^{2+}\right]_{i}$ are expressed as percentages of the total number of cells tested, excluding nonresponsive cells, which represented about $1 \%$ of the cells tested. The data are means \pm standard deviation (SD) or standard error (SE). Unpaired $t$-tests were used to calculate significance (Prism, GraphPad, USA).

\section{Results}

GTP-induced and ATP-induced [Ca $\left.{ }^{2+}\right]_{i}$ increases in M1-CCD cells

Application of both GTP and ATP produced rises in $\left[\mathrm{Ca}^{2+}\right]_{\mathrm{i}}$ in M1-CCD cells, which were measured in single living cells by monitoring the changes in fluorescence of the intracellular ratiometric dye Fura-2.

Cells were stimulated with $500 \mu \mathrm{M}$ GTP in the presence of external $\mathrm{Ca}^{2+}$ in the medium. Stimulation with GTP induced two different typologies of $\left[\mathrm{Ca}^{2+}\right]_{\mathrm{i}}$ increases in the M1-CCD 


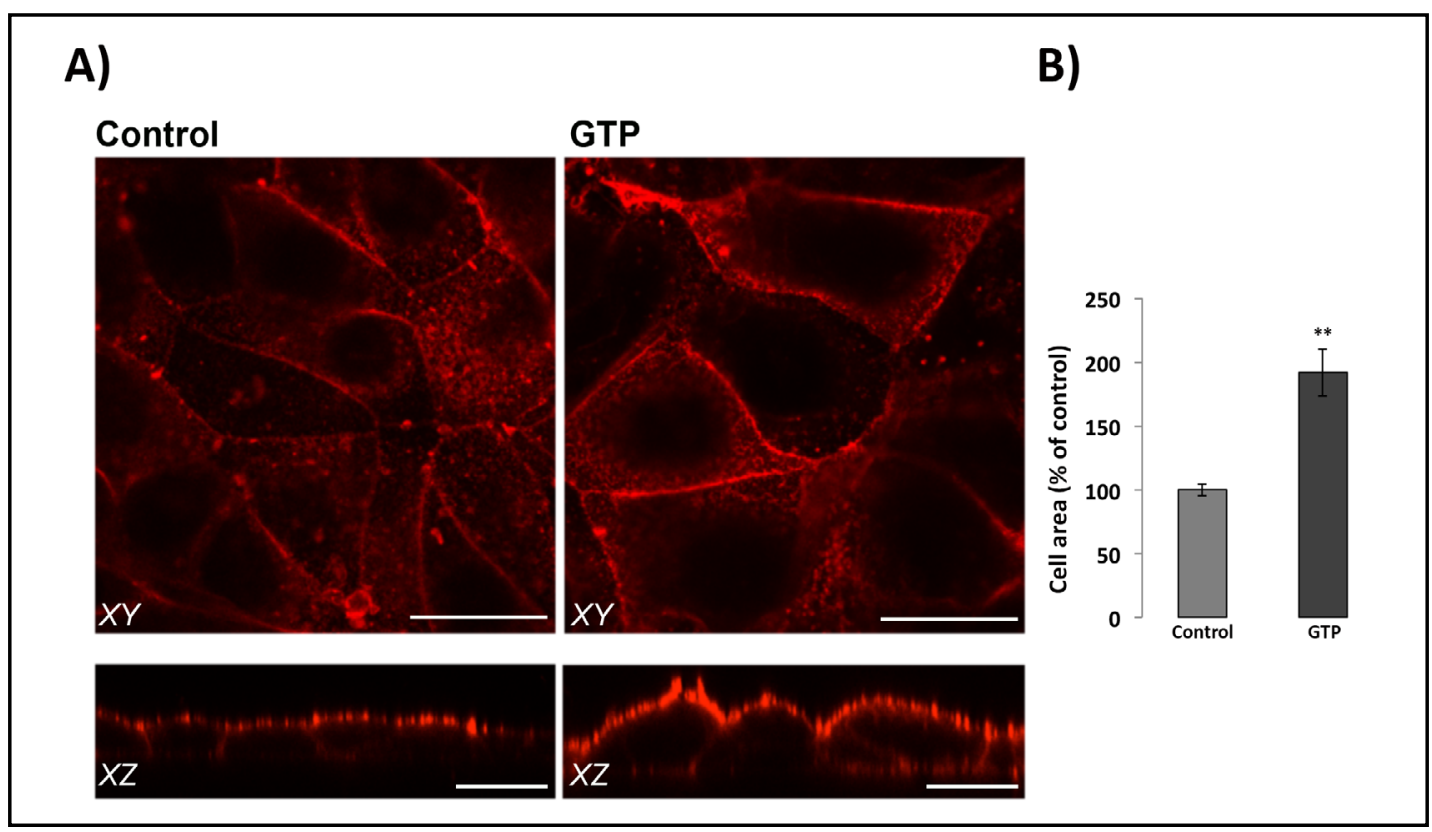

Fig. 2. GTP-dependent increase in the dimensions of the M1-CCD cells. A) M-1 CCD cells were cultured in the absence (control) or presence of $500 \mu \mathrm{M}$ GTP (GTP) for $72 \mathrm{~h}$. The cells were then fixed and stained with WGA-555. Representative images in the xy and xz planes taken with laser-scanning confocal microscopy. The presence of extracellular $500 \mu \mathrm{M}$ GTP induced increase in the M1-CCD cell areas. Bars, $20 \mu \mathrm{M}$. B) Cell surface area was accurately quantified using Image J software (http://rsb.info.nih.gov). The data are expressed as means \pm SEM; $n=60$. Cell area of M1-CCD control cells was set as $100 \%$. ${ }^{* *} \mathrm{P}<0.005$.

cells: in $25 \%$ of cells tested, there were GTP-induced oscillatory $\left[\mathrm{Ca}^{2+}\right]_{\mathrm{i}}$ kinetics (Fig. $1 \mathrm{~A}$ ), while in $75 \%$ of the cells there were typical $\left[\mathrm{Ca}^{2+}\right]_{i}$ transients (Fig. 1B). The GTP-dependent oscillatory $\left[\mathrm{Ca}^{2+}\right]_{\mathrm{i}}$ responses, recorded for about $5 \mathrm{~min}$, were characterized by a rapid $\left[\mathrm{Ca}^{2+}\right]_{\mathrm{i}}$ increase followed by several peaks of $\left[\mathrm{Ca}^{2+}\right]_{\mathrm{i}^{\prime}}$, each of which increased to about the same high $\left[\mathrm{Ca}^{2+}\right]_{\mathrm{i}}$ level (Fig. 1A). These specific oscillatory kinetics were never observed after stimulation with $500 \mu \mathrm{M}$ GTP in the absence of extracellular calcium in these M1-CCD cells (data not shown) suggesting that the extracellular calcium starts this specific response. The typical $\left[\mathrm{Ca}^{2+}\right]_{\mathrm{i}}$ transient induced by $500 \mu \mathrm{M}$ GTP in the presence of extracellular calcium consisted of a rapid $\left[\mathrm{Ca}^{2+}\right]_{\mathrm{i}}$ increase followed by a slow $\left[\mathrm{Ca}^{2+}\right]_{\mathrm{i}}$ decrease, which returned to basal levels in about $5 \mathrm{~min}$ (Fig. 1B). The same kinetics of $\left[\mathrm{Ca}^{2+}\right]_{\mathrm{i}}$ transients were also observed in all M1-CCD cells stimulated with $500 \mu \mathrm{M}$ GTP in the absence of extracellular calcium, even if the cells showed a lower increase in $\left[\mathrm{Ca}^{2+}\right]_{\mathrm{i}}$ (data not shown). Fig. 1C shows a representative response to $100 \mu \mathrm{M}$ ATP, with an increase in $\left[\mathrm{Ca}^{2+}\right]_{\mathrm{i}}$ upon ATP application that remained sustained for about $2 \mathrm{~min}$, followed by a decline to the initial baseline level in about $5 \mathrm{~min}$. These transient kinetics were seen for all of the responsive cells, both in the absence and presence of extracellular calcium (data not shown). We demonstrated in our previous study that the GTP-dependent $\left[\mathrm{Ca}^{2+}\right]_{\mathrm{i}}$ increase was blocked by suramin and RB2, generic purinergic receptor antagonists [6]. Therefore, we administered $250 \mu \mathrm{M}$ suramin at the peak of the GTP-dependent $\left[\mathrm{Ca}^{2+}\right]_{\mathrm{i}}$ increases recorded on these M1-CCD cells. Suramin significantly reduced the $\left[\mathrm{Ca}^{2+}\right]_{\mathrm{i}}$ transients (Fig. 1D). Similar results were obtained with RB2 (data not shown). To explore the involvement of P2Y2 on GTP response, we stimulated the same living cells with both ATP and then GTP. We stimulated the cells with $100 \mu \mathrm{M}$ ATP several times. When ATP no longer stimulates a $\left[\mathrm{Ca}^{2+}\right]_{\mathrm{i}}$ response, so P2Y2 was desensitized, we stimulated with $500 \mu \mathrm{M}$ GTP. GTP elicited its specific $\left[\mathrm{Ca}^{2+}\right]_{i}$ increase even in the presence of ATP (80\%; data not shown). 
Table 1. Half-life of extracellular GTP in presence of M1-CCD cells

\begin{tabular}{cccccccc}
\hline & \multicolumn{8}{c}{ Incubation time (h) } \\
& 0 & 1 & 3 & 5 & 7 & 10 & 24 \\
\hline$[\mathrm{GTP}] \pm \mathrm{SD}(\mu \mathrm{M})$ & $496 \pm 10$ & $430 \pm 22$ & $389 \pm 18$ & $360 \pm 18$ & $324 \pm 20$ & $281 \pm 16$ & $108 \pm 6$ \\
\hline
\end{tabular}

Fig. 3. Effects of long-term GTP treatment on water permeability in M1-CCD cells. M1-CCD cells were treated in the absence (CTR) or in the presence of $500 \mu \mathrm{M}$ GTP in culture medium for $24 \mathrm{~h}, 48 \mathrm{~h}$ and $72 \mathrm{~h}$. Water-permeability assays were carried out using a microfluorimetric assay (see Materials and Methods for details). The time constants of cell swelling induced by a hypotonic stimulus were obtained by fitting the line of the tangent to the first part of the curve using linear regression. The data are expressed as $1 / \tau\left(\mathrm{s}^{-1}\right)$, as means \pm SEM; $n$ $=35$. The time constant in M1-CCD control cells at each time point analyzed was set as $100 \%$. $* \mathrm{P}<0.05$; $* * * \mathrm{P}<0.0001$.

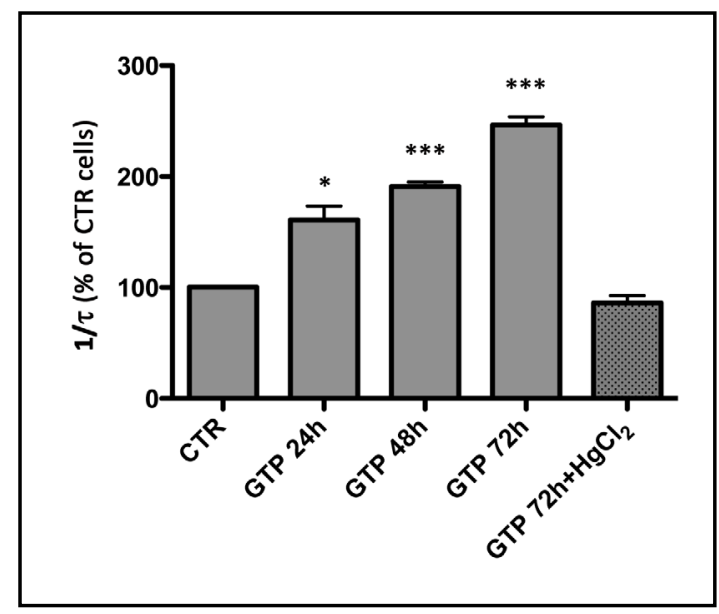

\section{Extracellular GTP induces cell-shape changes}

Addition of $500 \mu \mathrm{M}$ GTP to living M1-CCD cells also promoted a progressive increase in their cell dimensions after 24-48 $\mathrm{h}$ to $72 \mathrm{~h}$ of GTP stimulation. We observed that incubation of the cells with $500 \mu \mathrm{M}$ GTP for $7 \mathrm{~h}$ (followed by GTP washout with fresh medium) still resulted in increased cell size within the following $24 \mathrm{~h}$ (data not shown). Confocal images of WGA-555-stained cells were taken in the xy and xz planes (Fig. 2). We calculated that the cell area of the cells treated with $500 \mu \mathrm{M}$ GTP increased by about $90 \%$ after $72 \mathrm{~h}$ compared to control cells. With the purinergic antagonists (suramin and RB2) used in pre-incubations, $500 \mu \mathrm{M}$ GTP no longer induced these changes in the cell volumes seen after $24 \mathrm{~h}$ and $48 \mathrm{~h}$ of treatment (data not shown).

We performed experiments using ion-pair reversed-phase HPLC to determine the halflife of extracellular GTP in the presence of M1-CCD cells for 0 to $24 \mathrm{~h}$. The data reported in Table 1 demonstrate that when incubated with M1-CCD cells, $65 \%$ of the GTP remains stable for $7 \mathrm{~h}$, with its linear decrease showing a half-life of about $12 \mathrm{~h}$.

\section{Extracellular GTP increases AQP-mediated cellular water permeability}

To determine whether the increases in cell volume induced by GTP are a result of changes in the water permeability across the plasma membrane, we performed functional assays based on calcein fluorescence quenching. This is a well-established method for the measurement of rapid osmotic water transport in monolayers of cultured cells [22]. These functional assays were performed using a fluorimetric plate reader, as described in the Materials and Methods. The time constant of cell swelling induced by a hypotonic stimulus was obtained by fitting the line of the tangent to the first part of the curve using linear regression. The data were expressed as $1 / \tau\left(\mathrm{s}^{-1}\right)$ and are reported in Figure 3.

Treatment of M1-CCD cells with GTP clearly promoted significant increases in the rates of cell swelling induced by osmotic challenges at $24 \mathrm{~h}$ after GTP addition to the culture medium. The effect was further increased at $48 \mathrm{~h}$ and $72 \mathrm{~h}$ after GTP addition. Moreover, the effect of GTP was completely prevented by pre-incubation of the cells with $\mathrm{HgCl}_{2}$, a potent inhibitor of AQP-mediated water transport. No effect on water permeability was seen after FK incubation at each time point (not shown). 
Fig. 4. Flow cytometry analysis of surface expression of AQP5 in M1-CCD cells before and after GTP treatment. Representative dot plot from flow cytometry analysis of M1-CCD cells before and after $500 \mu \mathrm{M}$ GTP treatment for 48 $h$, as labelled with the antiAQP5 extracellular C-loop antibodies. The gated area delineated by the continuous line identifies cells positive for antibody cross-reactions, with percentages of positive cells given. A) Dot plot of the aspecific signal generated from Zenon labelling Kit (Left). Istogram represents the quantification of percentages of positive cells before (gray) and after (black) $500 \mu \mathrm{M}$ GTP treatment. B) Representative dot plot of AQP5 extracellular C-loop surface expression in untreated (left) ant treated

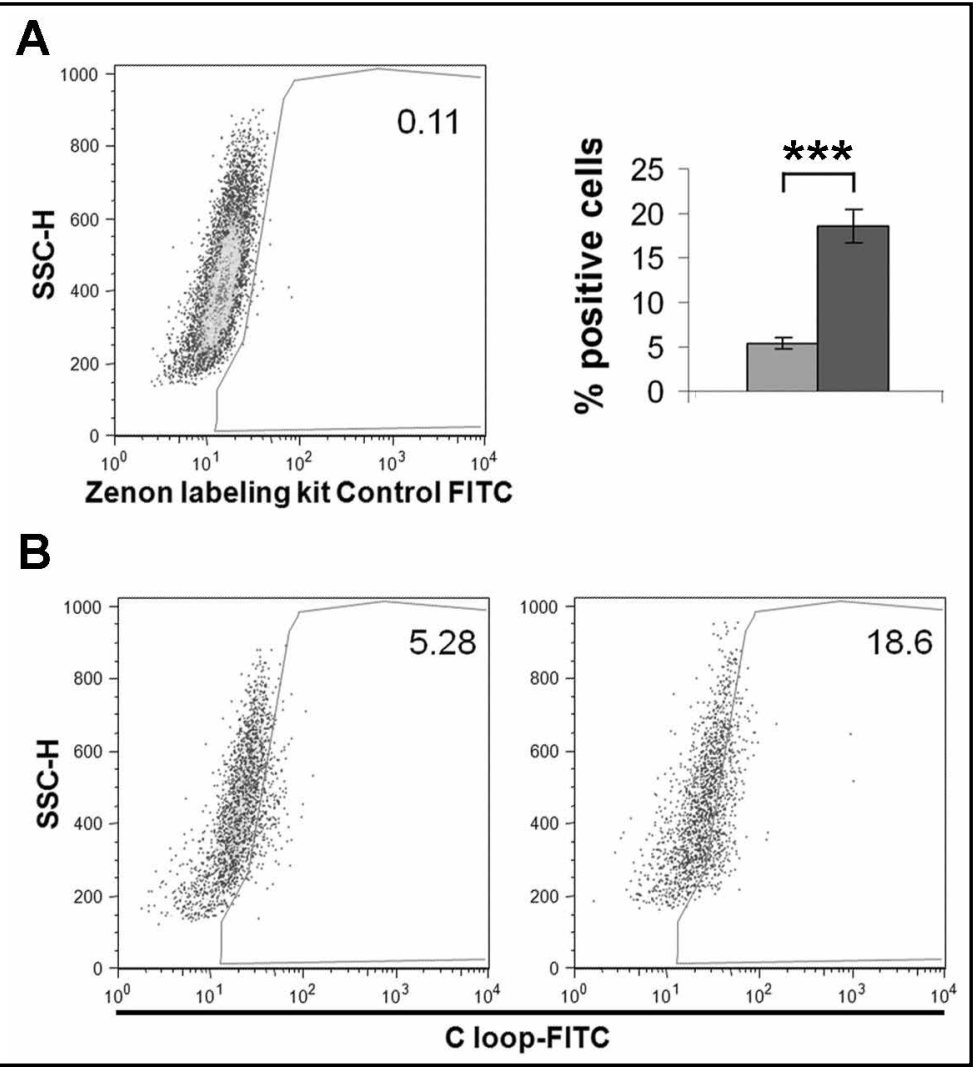
(right) cells with $500 \mu \mathrm{M}$ GTP for $48 \mathrm{~h}$. Data are means \pm SD, and are representative of three independent biological samples. ${ }^{* * *} \mathrm{P}<0.001$.

\section{Extracellular GTP induces AQP5 gene expression}

As previously demonstrated, M1-CCD cells show both principal cell (PC) and intercalated cell (IC) functions and antigens [24]. For this reason we investigated the expression of the collecting duct-specific AQPs in M1-CCD cells before and after the GTP incubation.

Gene expression analysis was performed by real-time PCR using primers for $A Q P 2$, $A Q P 5$ and $A Q P 6$, expressed in PCs, type-B ICs and type A ICs. M1-CCD cells were incubated for $12 \mathrm{~h}, 24 \mathrm{~h}$ and $48 \mathrm{~h}$ with $500 \mu \mathrm{M}$ GTP, $100 \mathrm{ATP} \mu \mathrm{M}$ or $500 \mu \mathrm{M}$ guanosine. The results obtained show that GTP clearly promoted the expression of AQP5. The fold change at 12 $\mathrm{h}$ was $1,063 \pm 0,123$, at $24 \mathrm{~h}$ was $1,205 \pm 0,165$, and at $48 \mathrm{~h}$ was $1,945 \pm 0,395$ (means \pm SE, $\mathrm{p} \leq 0,05$ ); while guanosine and ATP did not modify $A Q P 5$ expression at any time (data not shown). None of the stimuli promoted expression of $A Q P 2$ or $A Q P 6$. In particular, $A Q P 2$ mRNA was not detectable in these cells, and AQP6 mRNA was amplified only after 36 realtime PCR cycles (data not shown). Moreover, we stimulated the cells with GTP for $1 \mathrm{~h}, 3 \mathrm{~h}$ and $7 \mathrm{~h}$ in the culture medium, and then added fresh medium for up to $24 \mathrm{~h}$, when the cells were collected and analyzed by RT-PCR for AQP5 mRNA expression. The results obtained clearly show that the presence of GTP for $7 \mathrm{~h}$ promotes a significant AQP5 mRNA up-regulation, compared to control cells. The mean fold-change in the AQP5 mRNA levels was $2.30 \pm 0.41$ in cells stimulated for $7 \mathrm{~h}$, as compared to control cells and normalized versus GAPDH. After $1 \mathrm{~h}$ and $3 \mathrm{~h}$ of GTP stimulation, AQP5 mRNA was not significantly upregulated. We repeated the experiment in the presence of $2 \mathrm{mM}$ EGTA (to chelate the $\mathrm{Ca}^{++}$in the medium), and showed that the presence of EGTA completely prevented the AQP5 mRNA up-regulation (data not shown). 
Fig. 5. GTP induced AQP5 protein expression. Representative Western blotting of the total AQP5 protein content $24 \mathrm{~h}, 48 \mathrm{~h}$ and 72 $\mathrm{h}$ after $500 \mu \mathrm{M}$ GTP stimulation in M1-CCD cells, along with the positive control mouse lung (Ms lung). Right: Quantification of protein abundance by densitometric analysis. The graph shows the means and SD of three independent experiments. ${ }^{* * *} \mathrm{P}<0.0001$.

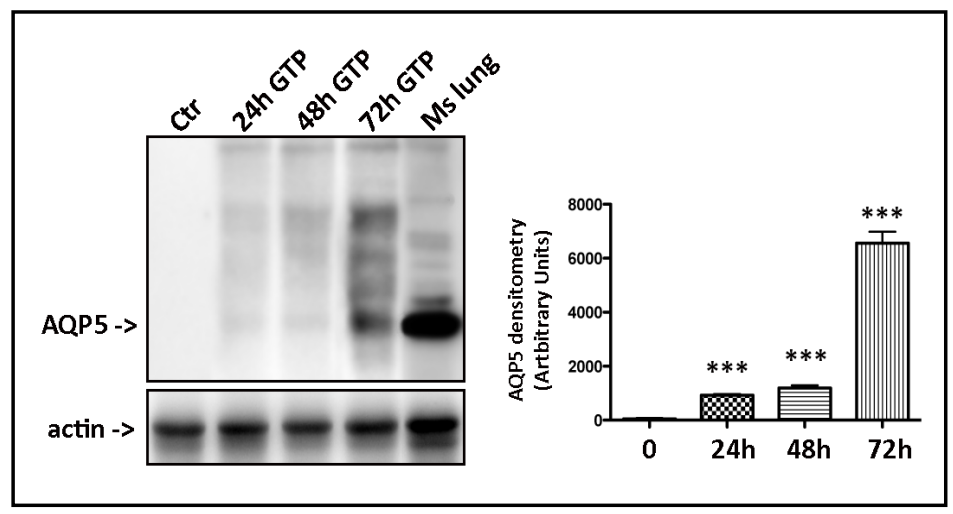

Extracellular GTP induces AQP5 plasma-membrane expression

Having demonstrated that AQP5 mRNA specifically increases after incubation with GTP, we next investigated whether GTP also induces increases in AQP5 plasmamembrane protein expression. Flow cytofluorimetry was used, taking advantage of a polyclonal antibody generated against amino acids 112-126 in the extracellular C-loop of human AQP2, as previously characterized [18]. Since the extracellular C-loop of mouse AQP5 (ARGNLAVNALSNNTT) shares 80\% homology with the C-loop of human AQP2 (IRGDLAVNALSNSTT), the anti-AQP2 antibody is predicted to recognize AQP5 as well.

In the flow cytofluorimetry shown in Figure 4A, B, the gate identified the area of positive events. When expressed as percentages of cells stained by the FITC-labeled anti-AQP5 C-loop antibody, after $48 \mathrm{~h}$ of GTP treatment this increased from $5.3 \%$ in untreated cells to $18.6 \%$ in GTP-treated cells. Of note, when the GTP-treated cells where detached using the proteolytic enzyme trypsin, the cross-reactivity to the C loop-FITC antibodies disappeared (data not shown). We also performed Western blotting to demonstrate that the total AQP5 protein content was significantly higher in GTP-treated M1-CCD cells compared to control cells. In line with the results of quantitative RT-PCR and the water-permeability assay, the densitometric analysis demonstates that the AQP5 protein showed a time-dependent increase following incubation with GTP (Fig. 5).

Proliferation assays and cell-cycle analysis

To determine the effects of GTP on the proliferation rate of M1-CCD cells, the cells were incubated with $500 \mu \mathrm{M}$ GTP for $24 \mathrm{~h}$ to $72 \mathrm{~h}$. GTP significantly inhibited the percentages of the cell growth rate by about $20 \%$ at each time point (data not shown). The percentages of dead cells were similar between control and treated cells (data not shown). We also tested the effect of ATP $(100$ and $500 \mu \mathrm{M})$ on the M1-CCD cell proliferation rate, with no effects seen (data not shown).

The effects of GTP on M1-CCD cell growth suggested the possibility of changes in cellcycle distribution. To address this possibility, we analyzed the cell-cycle distribution of these M1-CCD cells treated with $500 \mu \mathrm{M}$ GTP by flow cytometry. Cells were cultured in growth medium with $500 \mu \mathrm{M}$ GTP for $48 \mathrm{~h}$ and analyzed. The data demonstrated that $500 \mu \mathrm{M}$ GTP induced an accumulation of $20 \%$ of the cells tested in the S-phase; ATP $(100 \mu \mathrm{M})$ did not produce this cell-cycle block (Fig. 6). During the flow cytometry analysis, we also evaluated cell death. In the acquired cell patterns, the percentages of hypodiploid cells was considered to represent apoptotic cells. These data revealed that throughout the $48 \mathrm{~h}$ of incubation period, the mean percentage of apoptotic cells was very low $(<8 \%)$, and there was no significant difference between the control and the GTP-treated cells (data not shown). It is worth mentioning that when the GTP-treated cells were detached and resuspended in GTPfree media for $3 \mathrm{~h}$ before the cytofluorimetric analysis, the GTP-dependent block in S-phase was overcome (data not shown). 


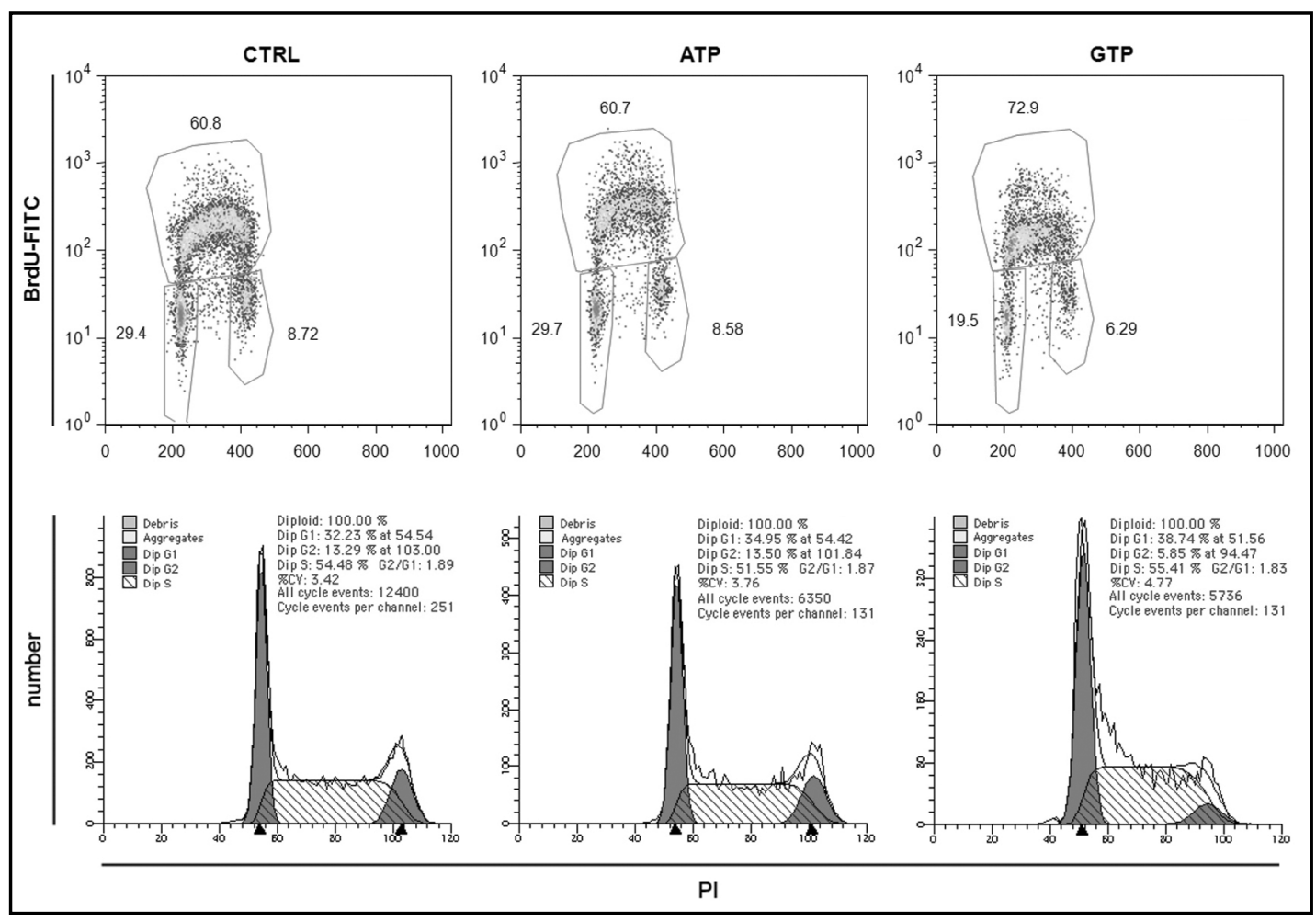

Fig. 6. Flow cytometry cell-cycle analysis of M1-CCD cells in the presence of GTP and ATP. Representative cell distributions (BrdU-FITC positivity) of the G1-, G2- and S-phases of the cell cycle of M1-CCD cells treated without (CTRL) and with $500 \mu \mathrm{M}$ GTP or $100 \mu \mathrm{M}$ ATP for $48 \mathrm{~h}$. Upper panels: biparametric BrdU (Y-axis)/ DNA (X-axis) analyses after $1 \mathrm{~h}$ of a $10 \mu \mathrm{M}$ BrdU pulse. Control: S, 60.8\%; G1, 29.4\%; G2, 8.72\%. Treatment for $48 \mathrm{~h}$ with ATP did not significantly modify this distribution. Treatment for $48 \mathrm{~h}$ with $500 \mu \mathrm{M}$ GTP showed significantly increased percentage of cells in S-phase, to $72.9 \%$, and significantly decreased percentage of cells in G1-phase, to $19.5 \%$ ( $\mathrm{p} \leq 0,05$, respectively). These data suggest that GTP promotes a G1 to S-phase shift. Lower panels: Corresponding DNA curve fitting, obtained using the ModFit LT ${ }^{\mathrm{TM}}$ software. Data are representative of three independent experiments.

\section{Discussion}

In the present study, we show compelling evidence of a novel role of extracellular GTP as a physiological regulator of AQP5-mediated water transport in a kidney epithelial cell line. We have demonstrated that $500 \mu \mathrm{M}$ GTP stimulates $\left[\mathrm{Ca}^{2+}\right]_{\mathrm{i}}$ increases with two different kinetics: oscillating $\left[\mathrm{Ca}^{2+}\right]_{\mathrm{i}}$ increases, and the typical $\left[\mathrm{Ca}^{2+}\right]_{\mathrm{i}}$ transient increase. The typical $\left[\mathrm{Ca}^{2+}\right]_{\mathrm{i}}$ transient has been extensively described as the typical $\left[\mathrm{Ca}^{2+}\right]_{\mathrm{i}}$ increase induced by purines [25], while the oscillatory $\left[\mathrm{Ca}^{2+}\right]_{\mathrm{i}}$ increases were not expected and have never been observed in our previous studies on GTP-dependent $\left[\mathrm{Ca}^{2+}\right]_{\mathrm{i}}$ modulation in neuronallike or skeletal muscle cells $[8,10]$. We believe that these GTP-induced oscillating $\left[\mathrm{Ca}^{2+}\right]_{\mathrm{i}}$ increases, which are strictly dependent on the presence of extracellular $\mathrm{Ca}^{2+}$, might be linked to the specific GTP signaling. We also show that GTP induces $20 \%$ of the M1-CCD cells to be blocked in S-phase of the cell cycle, a percentage that we note is similar to that of cells showing oscillatory $\left[\mathrm{Ca}^{2+}\right]_{\mathrm{i}}$ increases. We have previously demonstrated in a skeletal muscle cell line that $500 \mu \mathrm{M}$ GTP induce S-phase block in about 15\% of C2C12 cells after $24 \mathrm{~h}$ of incubation [10]. Furthermore, in the neuronal cell model of SH-SY5Y cells, GTP promotes cell accumulation in S-phase, starting from $24 \mathrm{~h}$ of purine exposure and extending for up to 6 days [8]. In mesenchymal stem cells, it has been demonstrated that $\mathrm{Ca}^{2+}$ channels regulate cell-cycle progression and proliferation through modulation of cyclin expression [26]. 
Other studies have demonstrated that the G1/S phase transition is uniquely characterized by spontaneous $\left[\mathrm{Ca}^{2+}\right]_{i}$ oscillations [27]. Moreover, a spontaneous release of nucleotides resulting in P2-receptor-dependent $\left[\mathrm{Ca}^{2+}\right]_{\mathrm{i}}$ oscillations was observed in renal epithelial cells [28]. Considering these data, we believe that the GTP-triggered calcium signaling in M1-CCD renal epithelial cells is crucial for their physiological functions. As noted, the percentage of cells that were accumulated in S-phase after treatment with $500 \mu \mathrm{M}$ GTP was $20 \%$ more than control cells, the same percentage as the growth-rate reduction induced by GTP. It is thus most likely that the inhibition of proliferation is exclusively due to the cell S-phase block, as GTP did not induce cell apoptosis or aspecific cell death. Extracellular ATP is known to stimulate proliferation of numerous cancer cell types, as well as of cells in the central nervous system and myoblasts $[3,29,30]$. Indeed, in the present study, ATP had completely different effects with respect to GTP. ATP neither induce $\left[\mathrm{Ca}^{2+}\right]_{\mathrm{i}}$ oscillations, nor blocked cell proliferation, nor induced S-phase arrest. Based on the evidence presented here, we can only hypothesize a link between the GTP-induced $\left[\mathrm{Ca}^{2+}\right]_{\mathrm{i}}$ oscillation and the S-phase block. In addition to having a specific role in promoting the GTP-induced $\left[\mathrm{Ca}^{2+}\right]_{\mathrm{i}}$ oscillations, the presence of extracellular $\mathrm{Ca}^{2+}$ was important also to sustain the transient GTP-induced$\left[\mathrm{Ca}^{2+}\right]_{\mathrm{i}}$ increase and it was crucial for triggering GTP-induced expression of AQP5 mRNA. Indeed, $7 \mathrm{~h}$ of exposure to GTP triggered its specific signal transduction via $\left[\mathrm{Ca}^{2+}\right]_{\mathrm{i}}$ increases, which induced the expression of AQP5 mRNA only in the presence of extracellular calcium. As we previously demonstrated in the kidney, the AQP5 isoform is a water channel that is constitutively expressed at the plasma membrane of renal cells [17].

The question regarding the source of extracellular GTP in native tissues is still unresolved. Several equally attractive pathways have been suggested, such as vesicular release or transport through $\mathrm{ABC}$ proteins, cystic fibrosis transmembrane conductance regulator and P-glucoprotein, and connexin hemichannels and pannexins [4, 31-33]. At the same time, even if we do not know the concentration that GTP can reach in vivo in the extracellular fluids, it has been reported that its basal intracellular concentrations range between $200 \mu \mathrm{M}$ and $500 \mu \mathrm{M}$ [34]. In the site of tissue lesions, higher GTP levels have also been reported near the site of disrupted cells, with this situation hypothesized in various studies as the possible mechanism of guanine-based purine-mediated cell repair, at least in the nervous system $[35,36]$.

More recently, it has been suggested that ATP is released as a co-transmitter from sympathetic nerve varicosities, and that it can bind the basolateral P2 purinoceptors and influence sodium and water transport $[37,38]$. However, one of the major issues in understanding purinergic signaling continues to be the limited consensus for the nucleotide release phenomenon. We believe that the GTP source, as already been seen for ATP, might be different: the autonomic neurons, the mechanical stress and the pannexin channels [39], the hypoxic environments, the inflammation [40]. More recently, Contreras-Sanz demonstrated that GTP can be found in samples of varying complexity, such as M1-CCD cells and human urine samples [41]. Moreover, another source could be linked to the physiological turnover during cell damage or death, in fact the metabolized nucleic acids (DNA, RNA, etc) could account for a large amount of guanine based purines [36]. Additionally, changes in the intracellular osmolality and in the tension of membranes might cause some non-vesicular release of purines, as previously demonstrated in glial cells [42]. We speculate that in the kidney GTP might be released as autocrine or paracrine factor into the interstitial spaces, recognize specific binding sites on the epithelial cells, trigger $\left[\mathrm{Ca}^{2+}\right]_{\mathrm{i}}$ increases and activate a signal transduction pathway leading to AQP5 mRNA upregulation. The quantitative realtime PCR experiments in the present study indicated significant and time-dependent upregulation of AQP5 mRNA in M1-CCD cells starting $7 \mathrm{~h}$ after GTP exposure, as compared to control cells. Western blotting confirmed that in GTP-stimulated M1-CCD cells AQP5 protein abundance is increased $24 \mathrm{~h}$ after exposure to GTP. Using a cytofluorimetric assay, we also demonstrated that in intact M1-CCD cells treated with GTP, AQP5 was accessible to a polyclonal antibody directed to its extracellular C-loop, thus indicating that AQP5 is expressed at the plasma membrane. The cell surface expression of AQP5 in GTP-treated M1- 
CCD cells is in line with the plasma-membrane expression of AQP5 in the kidney [17] and in extra-renal cells [43-46].

Membrane-associated AQPs have been implicated in volume changes in whole cells, intracellular vesicles, secretory granules and synaptic vesicles [25, 47-51]. Even at constant extracellular osmolality, the cell volume constancy is compromised by alterations in intracellular osmolality [52]. A wide variety of metabolic pathways lead to the formation in the cell of osmotically active substances. The expression of a functional water channel in GTP-treated M1-CCD cells would facilitate water influx and explain the observed increases in cell size. It should be kept in mind, however, that following cell swelling, volume regulatory mechanisms will decrease the intracellular osmolality and the cell volume, thus providing a regulatory cell volume decrease and re-establishing the original cell volume [53]. GTP might thus regulate cell-volume regulatory mechanisms.

In support of our hypothesis, the water permeability measurements performed using the Flexa station confirmed that long-term GTP exposure significantly increases the rate of osmotically induced cell swelling in M1-CCD cells. Moreover, this increase was completely abolished by $\mathrm{HgCl}_{2}$, a specific inhibitor of $\mathrm{AQP}$-mediated water transport.

The quantitative real-time PCR experiments that were performed using a panel of probes specific for renal AQPs indicated that the mRNA levels of the two other collectingduct-specific AQPs, AQP2 and AQP6, were not affected by long-term GTP exposure (data not shown).

In contrast, ATP did not affect $A Q P 5$ gene expression after $48 \mathrm{~h}$ of incubation. It is worth mentioning that two purinergic receptors, P2Y2 and P2Y4, might also bind GTP, although with lower affinity compared to ATP and UTP, and thus might transduce the signal within the cell [54]. In particular, in our cellular model, we found the mRNA expression for P2Y2 (confirmed by Western Blot analysis) but not for P2Y4 receptors (data not shown). However, following repeated stimulation with ATP in order to desensitize the P2Y2R, we still were able to record oscillating $\left[\mathrm{Ca}^{2+}\right]_{\mathrm{i}}$ responses after GTP application (data not shown). Our results on calcium signaling suggested that ATP cannot desensitize the 'GTP signaling' because probably they activate different molecular targets. Moreover, ATP was not able to modify the expression of AQP5. However, the results on calcium responses using Suramin and RB2 as generic purinergic antagonists, even with their limits as good purinergic antagonists, suggested us that GTP acts on the "purinergic area".

Moreover, $A Q P 5$ gene up-regulation is strictly linked to the triphosphate form of guanine-based purines, as guanosine did not mimic the effects of GTP. We also strengthen this concept by demonstrating that CD73, a 70-kDa GPI-anchored cell-surface enzyme that catalyzes the extracellular conversion of phosphonucleotide esters into their respective nucleosides [55], is not present in the plasma membrane of M1-CCD cells (data not shown), and that the half-life of GTP in the presence of M1-CCD cells is about $12 \mathrm{~h}$ (Table 1). Our data are in agreement with data obtained in a recent study by Contreras-Sanz [41].

We recently reported the novel observation that AQP5 is expressed at the apical plasma membrane of type-B ICs in the kidney [17]. It does not come as a surprise, therefore, that incubation with GTP can induce AQP5 expression in M1-CCD cells that show a intermediate phenotype between PCs and ICs [24].

The management of cellular water fluxes is of a great interest in cell biology, as this involves cell-volume regulation, and the regulation of all other processes that depend on it.

In conclusion, we have demonstrated for the first time that extracellular GTP can induce functional AQP5 plasma-membrane expression in a cell model of epithelial cortical collecting duct cells, M1-CCD cells. As a consequence, GTP can facilitate water transport into the cell and cell swelling. This observation is in line with our hypothesis that AQP5 acts as osmosensor of the luminal fluid osmolality in the collecting duct [17]. This is the first study addressing a novel function of GTP in renal epithelial cells, and we believe that our data should solicit future investigations into guanine-based purine functions in renal physiology and physiopathology. 
Mancinelli et al.: GTP Induces AQP5 Expression in Renal Epithelial Cells

\section{Aknowledgments}

This study was supported by the following research grants: 'G. d'Annunzio' University of Chieti-Pescara to TP; 'Carichieti' Foundation, Chieti, Italy, and by the Italian MIUR: Cofunding research projects of national interest (COFIN) 2009 Grant PRIN 2009J53ALK to MS and 2012N8YJC3 to TP; FIRB 2010 "accordi di programma" to SM and 2012 FIRB prot. RBFR12BUMH_005 to RM. We would like to thank Dr Ester Di Filippo for helping us in the organization of some of the experiments, Drs Mirko Zucchelli and Federica Forlì for performing HPLC analyses and Christopher Berrie for helpful discussion.

\section{Conflicts of Interest}

The authors have no conflicts of interest to declare.

\section{References}

1 Burnstock G: Introductory overview of purinergic signalling. Front Biosci (Elite Ed) 2011;3:896-900.

-2 Burnstock G, Evans LC, Bailey MA: Purinergic signalling in the kidney in health and disease. Purinergic Signal 2013; doi 10.1007/s11302-013-9400-5.

3 Deli T, Csernoch L: Extracellular atp and cancer: An overview with special reference to p2 purinergic receptors. Pathol Oncol Res 2008;14:219-231.

-4 Forrester T: A case of serendipity*. Purinergic Signal 2008;4:93-100.

5 Gysbers JW, Guarnieri S, Mariggio MA, Pietrangelo T, Fano G, Rathbone MP: Extracellular guanosine 5' triphosphate enhances nerve growth factor-induced neurite outgrowth via increases in intracellular calcium. Neuroscience 2000;96:817-824.

6 Pietrangelo T, Mariggio MA, Lorenzon P, Fulle S, Protasi F, Rathbone M, Werstiuk E, Fano G: Characterization of specific gtp binding sites in c2c12 mouse skeletal muscle cells. J Muscle Res Cell Motil 2002;23:107-118.

7 Ciccarelli R, Di Iorio P, Giuliani P, D'Alimonte I, Ballerini P, Caciagli F, Rathbone MP: Rat cultured astrocytes release guanine-based purines in basal conditions and after hypoxia/hypoglycemia. Glia 1999;25:93-98.

-8 Guarnieri S, Pilla R, Morabito C, Sacchetti S, Mancinelli R, Fano G, Mariggio MA: Extracellular guanosine and gtp promote expression of differentiation markers and induce s-phase cell-cycle arrest in human sh-sy5y neuroblastoma cells. Int J Dev Neurosci 2009;27:135-147.

-9 Neary JT, Rathbone MP, Cattabeni F, Abbracchio MP, Burnstock G: Trophic actions of extracellular nucleotides and nucleosides on glial and neuronal cells. Trends Neurosci 1996;19:13-18.

10 Pietrangelo T, Fioretti B, Mancinelli R, Catacuzzeno L, Franciolini F, Fano G, Fulle S: Extracellular guanosine5 '-triphosphate modulates myogenesis via intermediate $\mathrm{Ca}^{2+}$-activated $\mathrm{K}^{+}$currents in c2c12 mouse cells. J Physiol 2006;572:721-733.

11 Mancinelli R, Pietrangelo T, Burnstock G, Fano G, Fulle S: Transcriptional profile of gtp-mediated differentiation of c2c12 skeletal muscle cells. Purinergic Signal 2012;8:207-221.

12 Moosavi MA, Yazdanparast R, Lotfi A: Gtp induces s-phase cell-cycle arrest and inhibits DNA synthesis in k562 cells but not in normal human peripheral lymphocytes. J Biochem Mol Biol 2006;39:492-501.

-13 Meshkini A, Yazdanparast R, Nouri K: Intracellular gtp level determines cell's fate toward differentiation and apoptosis. Toxicol Appl Pharmacol 2011;253:188-196.

14 Vallon V, Rieg T: Regulation of renal nacl and water transport by the atp/utp/p2y2 receptor system. Am J Physiol Renal Physiol 2011;301:F463-475.

15 Wildman SS, Boone M, Peppiatt-Wildman CM, Contreras-Sanz A, King BF, Shirley DG, Deen PM, Unwin RJ: Nucleotides downregulate aquaporin 2 via activation of apical p2 receptors. J Am Soc Nephrol 2009;20:1480-1490.

16 Stoos BA, Naray-Fejes-Toth A, Carretero OA, Ito S, Fejes-Toth G: Characterization of a mouse cortical collecting duct cell line. Kidney Int 1991;39:1168-1175. 


\section{Cellular Physiology Cell Physiol Biochem 2014;33:731-746

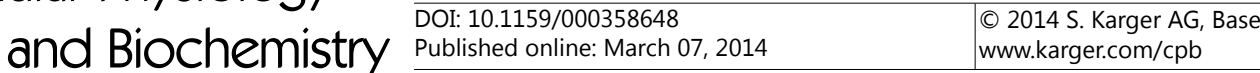 \\ Mancinelli et al.: GTP Induces AQP5 Expression in Renal Epithelial Cells}

17 Procino G, Mastrofrancesco L, Sallustio F, Costantino VBC, Pisani F, Schena FPSM, Valenti G: Aqp5 is expressed in type-b intercalated cells in the collecting duct system of the rat, mouse and human kidney. Cell Physiol Biochem 2011;28:683-692.

18 Gouraud S, Laera A, Calamita G, Carmosino M, Procino G, Rossetto O, Mannucci R, Rosenthal W, Svelto M, Valenti G: Functional involvement of vamp/synaptobrevin-2 in camp-stimulated aquaporin 2 translocation in renal collecting duct cells. J Cell Sci 2002;115:3667-3674.

-19 Lanuti P, Fuhrmann S, Lachmann R, Marchisio M, Miscia S, Kern F: Simultaneous characterization of phospho-proteins and cell cycle in activated t cell subsets. Int J Immunopathol Pharmacol 2009;22:689698.

20 Maecker HT, Trotter J: Flow cytometry controls, instrument setup, and the determination of positivity. Cytometry A 2006;69:1037-1042.

-21 Roederer M: Spectral compensation for flow cytometry: Visualization artifacts, limitations, and caveats. Cytometry 2001;45:194-205.

22 Procino G, Barbieri C, Carmosino M, Tamma G, Milano S, De Benedictis L, Mola MG, Lazo-Fernandez Y, Valenti G, Svelto M: Fluvastatin modulates renal water reabsorption in vivo through increased aqp2 availability at the apical plasma membrane of collecting duct cells. Pflugers Arch 2011;462:753-766.

23 Erba E, Bergamaschi D, Bassano L, Damia G, Ronzoni S, Faircloth GT, D'Incalci M: Ecteinascidin-743 (et743), a natural marine compound, with a unique mechanism of action. Eur J Cancer 2001;37:97-105.

-24 Fejes-Toth G, Naray-Fejes-Toth A: Differentiation of renal beta-intercalated cells to alpha-intercalated and principal cells in culture. Proc Natl Acad Sci USA 1992;89:5487-5491.

-25 Kishore BK, Nelson RD, Miller RL, Carlson NG, Kohan DE: P2y(2) receptors and water transport in the kidney. Purinergic Signal 2009;5:491-499.

-26 Tao R, Lau CP, Tse HF, Li GR: Regulation of cell proliferation by intermediate-conductance $\mathrm{Ca}^{2+}$-activated potassium and volume-sensitive chloride channels in mouse mesenchymal stem cells. Am J Physiol Cell Physiol 2008;295:C1409-1416.

-27 Russa AD, Maesawa C, Satoh Y: Spontaneous [ca2+]i oscillations in g1/s phase-synchronized cells. J Electron Microsc (Tokyo) 2009;58:321-329.

28 Geyti CS, Odgaard E, Overgaard MT, Jensen ME, Leipziger J, Praetorius HA: Slow spontaneous $\left[\mathrm{Ca}^{2+}\right]_{\mathrm{i}}$ oscillations reflect nucleotide release from renal epithelia. Pflugers Arch 2008;455:1105-1117.

29 Abbracchio MP, Burnstock G, Verkhratsky A, Zimmermann H: Purinergic signalling in the nervous system: An overview. Trends Neurosci 2009;32:19-29.

-30 Martinello T, Baldoin MC, Morbiato L, Paganin M, Tarricone E, Schiavo G, Bianchini E, Sandona D, Betto R: Extracellular atp signaling during differentiation of c2c12 skeletal muscle cells: Role in proliferation. Mol Cell Biochem 2011;351:183-196.

31 Bao L, Samuels S, Locovei S, Macagno ER, Muller KJ, Dahl G: Innexins form two types of channels. FEBS Lett 2007;581:5703-5708.

-32 Cotrina ML, Lin JH, Alves-Rodrigues A, Liu S, Li J, Azmi-Ghadimi H, Kang J, Naus CC, Nedergaard M: Connexins regulate calcium signaling by controlling atp release. Proc Natl Acad Sci USA 1998;95:1573515740.

-33 Reisin IL, Prat AG, Abraham EH, Amara JF, Gregory RJ, Ausiello DA, Cantiello HF: The cystic fibrosis transmembrane conductance regulator is a dual atp and chloride channel. J Biol Chem 1994;269:2058420591.

34 Traut TW: Physiological concentrations of purines and pyrimidines. Mol Cell Biochem 1994;140:1-22.

35 Rathbone M, Pilutti L, Caciagli F, Jiang S: Neurotrophic effects of extracellular guanosine. Nucleosides Nucleotides Nucleic Acids 2008;27:666-672.

-36 Rathbone MP, Middlemiss PJ, Gysbers JW, Andrew C, Herman MA, Reed JK, Ciccarelli R, Di Iorio P, Caciagli F: Trophic effects of purines in neurons and glial cells. Prog Neurobiol 1999;59:663-690.

37 Loesch A, Unwin R, Gandhi V, Burnstock G: Sympathetic nerve varicosities in close apposition to basolateral membranes of collecting duct epithelial cells of rat kidney. Nephron Physiol 2009;113:15-21.

-38 Wildman SS, Kang ES, King BF: ENaC, renal sodium excretion and extracellular ATP. Purinergic Signal 2009;5:481-489.

39 D'Hondt C, Iyyathurai J, Vinken M, Rogiers V, Leybaert L, Himpens B, Bultynck G: Regulation of connexinand pannexin-based channels by post-translational modifications. Biol Cell 2013;105:373-398.

40 Bodin P, Burnstock G: Purinergic signalling: Atp release. Neurochem Res 2001;26:959-969. 


\begin{tabular}{|c|c|c|}
\hline Cellular Physiology & Cell Physiol Biochem 2014;33:731-746 & \\
\hline and Biochemistry & $\begin{array}{l}\text { DOI: 10.1159/000358648 } \\
\text { Publishea onine: warcn } 07,2014\end{array}$ & $\begin{array}{l}\text { O } 2014 \text { S. Karger AG, Basel } \\
\text { www.karger.com/cpb }\end{array}$ \\
\hline
\end{tabular}

41 Contreras-Sanz A, Scott-Ward TS, Gill HS, Jacoby JC, Birch RE, Malone-Lee J, Taylor KM, Peppiatt-Wildman CM, Wildman SS: Simultaneous quantification of 12 different nucleotides and nucleosides released from renal epithelium and in human urine samples using ion-pair reversed-phase hplc. Purinergic Signal 2012;8:741-751.

42 Martin DL: Synthesis and release of neuroactive substances by glial cells. Glia 1992;5:81-94.

-43 He X, Tse CM, Donowitz M, Alper SL, Gabriel SE, Baum BJ: Polarized distribution of key membrane transport proteins in the rat submandibular gland. Pflugers Arch 1997;433:260-268.

-44 Ishida N, Hirai SI, Mita S: Immunolocalization of aquaporin homologs in mouse lacrimal glands. Biochem Biophys Res Commun 1997;238:891-895.

45 Mhatre AN, Steinbach S, Hribar K, Hoque AT, Lalwani AK: Identification of aquaporin 5 (aqp5) within the cochlea: Cdna cloning and in situ localization. Biochem Biophys Res Commun 1999;264:157-162.

46 Nielsen S, King LS, Christensen BM, Agre P: Aquaporins in complex tissues. Ii. Subcellular distribution in respiratory and glandular tissues of rat. Am J Physiol 1997;273:C1549-1561.

47 Cho SJ, Sattar AK, Jeong EH, Satchi M, Cho JA, Dash S, Mayes MS, Stromer MH, Jena BP: Aquaporin 1 regulates gtp-induced rapid gating of water in secretory vesicles. Proc Natl Acad Sci U S A 2002;99:47204724 .

48 Jeremic A, Cho WJ, Jena BP: Involvement of water channels in synaptic vesicle swelling. Exp Biol Med (Maywood) 2005;230:674-680.

49 Knepper MA, Inoue T: Regulation of aquaporin-2 water channel trafficking by vasopressin. Curr Opin Cell Biol 1997;9:560-564.

50 Marinelli RA, Pham L, Agre P, LaRusso NF: Secretin promotes osmotic water transport in rat cholangiocytes by increasing aquaporin-1 water channels in plasma membrane. Evidence for a secretin-induced vesicular translocation of aquaporin-1. J Biol Chem 1997;272:12984-12988.

51 Yasui M, Hazama A, Kwon TH, Nielsen S, Guggino WB, Agre P: Rapid gating and anion permeability of an intracellular aquaporin. Nature 1999;402:184-187.

52 Lang F, Busch GL, Ritter M, Volkl H, Waldegger S, Gulbins E, Haussinger D: Functional significance of cell volume regulatory mechanisms. Physiol Rev 1998;78:247-306.

53 Lang F: Mechanisms and significance of cell volume regulation. J Am Coll Nutr 2007;26:613S-623S.

54 Thomas J, Deetjen P, Ko WH, Jacobi C, Leipziger J: P2y(2) receptor-mediated inhibition of amiloridesensitive short circuit current in m-1 mouse cortical collecting duct cells. J Membr Biol 2001;183:115-124.

55 Robson SC, Sevigny J, Zimmermann H: The e-ntpdase family of ectonucleotidases: Structure function relationships and pathophysiological significance. Purinergic Signal 2006;2:409-430. 